N-アセチル転移酵素および CYP2C19 多型の遺伝子診断と 薬物動態・治療効果との相関解析

O谷川原祐介 1)、喜多知子 1)、廣野満喜 1)、駒田富佐夫 1)、奥村勝彦 1) 青山伸郎 2)、白川勝朗 2)、阪井俊介 2)、春日雅人 2)

神戸大学医学部附属病院 1)薬剤部、2)第二内科

\title{
GENOTYPING OF POLYMORPHIC N-ACETYLTRANSFERASE AND CYP2C19 AND CORRELATION WITH PHARMACOKINETICS AND THERAPEUTIC EFFICACY
}

\author{
Yusuke TANIGAWARA ${ }^{1)}$, Tomoko KITA ${ }^{11}$, Maki HIRONO'), \\ Fusao KOMADA ${ }^{1)}$, Katsuhiko OKUMURA ${ }^{1)}$, Nobuo AOYAMA ${ }^{2)}$, \\ Katsuro SHIRAKAWA ${ }^{2)}$, Toshiyuki SAKAI ${ }^{2)}$, Masato KASUGA ${ }^{2)}$ \\ 1)Department of Hospital Pharmacy and 2)2nd Department of Internal \\ Medicine, School of Medicine, Kobe University, Kobe 650.
}

【目 的】近年、薬物代謝能の遺伝形質に 関する研究が進展し、多型性の原因となりう る遺伝子上の点突然変異の解明が進められて いる。この変異は in vitroにおける遺伝子診断 によって判定可能であるが、臨床的意義を明 確にするためには、遺伝子上の変異と体内動 態並びに薬効・副作用との相関解析が必要で ある。今回、我々は、多型性を示守代表的な 代謝醳素（N-アセチル転移酵素、チトクロー ム P-450 2C19）に関して、血液あるいは毛髪 等非血液検体を用いる簡易・迅速な遺伝子夕 イピング法を確立した。さらに、これらの酵 素によって代謝される薬物（イソニアジド、 プロカインアミド、オメプラゾール）につい て、体内動態・治療効果と遺伝子型との相関 解析を行なった。

【遺伝子タイピング (genotyping)】 遺伝子 上の変異は、制限醉素断片長多型 (restriction fragment length polymorphisms: RFLP) 法 により判定した。すなわち、末梢血白血球か ら抽出したゲノム DNA より変異部分を含む
目的部位を PCR 法により各々増幅した。次に、 制限酵素を用いて酵素処理を行った後、得ら れたフラグメントの電気泳動パターンから遺 伝子型を決定した。この PCR-RFLP 法による 遺伝子タイピングは、操作が簡便でかつ短期 間（約 2 日）に行えることから、臨床応用可 能な検査法である。

また、我々は毛髪、口腔粘膜、爪などの非 血液検体を利用する微量遺伝子診断法をも確

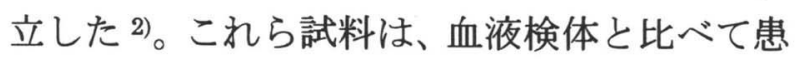
者の負担が少なく、且つ測定者への感染リス クという面からより簡便で安全と言える。本 法により、遺伝子タイピング用検体の新しい 選択肢も提供され、日常臨床への応用並びに 将来の大規模疫学研究において有用と期待さ れる。

【遺伝子型と薬物体内動態の相関】 N-アセ チル転移酵素（NAT2）は、アリルアミン系薬 物のアセチル化を担い、代謝速度の速い個体、 中間の個体、遅い個体の 3 種類の代謝型が存 在する。我々はイソニアジド、プロカインア 
ミド 1)の 2 薬剤について健常被験者を用いた 試験を行い、尿中並びに血中での代謝物／未 変化体比加遺伝子型（genotype）と表現型

(phenotype) との一致を認めた。

また、プロトンポンプ阻害剤のオメプラゾ ール (OMP)、ランソプラゾールは CYP2C19 による代謝多型が報告されており、 poor metabolizer(PM) と extensive metabolizer (EM) とは血中濃度に大きな差が認められる ことから、遺伝子型と治療効果との相関解析 を行なった。

\section{【CYP2C19 遺伝子型と H.pylori 除菌成績の}

関連】胃炎や消化性潰瘍に関わる $H$. pylori の除菌療法として、抗菌剤とプロトンポンプ 阻害剂の併用が注目を集めている。我々は OMP の H. pylori 除菌効果と CYP2C19 遺伝 子型との関連性について興味ある知見を得た。 方法は、H. pylori 陽性と判定された胃炎、胃・ 十二指腸潰瘍患者 79 例を 2 群に分け、 1 週間 の二剂併用療法（OPZ+アモキシシリン $\mathrm{AMPC}$ ) あるいは新三剂併用療法 (OPZ+AMPC+クラリスロマイシン CAM)を
実施した。除菌効果は、尿素呼気試験、組織 (Warthin-Starry)、および培養により判定した。

治療成績を CYP2C19 遺伝子型に基づいて 分類すると、EM 67 例における除菌率は約 40-88\%に過ぎないのに対し、PM では 12 例 全員が除菌できた。従って、PM の H. pylori 感染患者は、OMP と AMPC の二剂併用で除 菌できる可能性が高く、CAM などの耐性を生 じやすい抗菌薬の使用を避けられる点で有利 である。本研究により、遺伝子型に基づいて 最適な治療レジメを選択するという新しい治 療概念を提唱できた ${ }^{3)}$ 。

In vitro における遺伝子診断に基づいて代 謝能を予測し薬物治療に応用するには、遺伝 子型と表現型の相関性、さらに体内動態の差 異と治療効果との関連性に関する調査研究が 必要であり、これらは現在最も重要な課題と 考えられる。また、代謝活性は肝障害、併用 薬、喫煙などの環境要因の影響をも受けるこ とから、それらと遺伝子型との定量的寄与の 評価も必要であり、そのためには population pharmacokinetics 等の応用が今後期待される。

[ABSTRACT] N-acetyltransferase 2 (NAT2) and cytochrome P450 2C19 enzymes are known to exhibit a hereditarily determined polymorphism. The characterization of genetic variation at the DNA level for these enzymes has made it possible to determine an individual genotype. The common method is a polymerase chain reaction (PCR) and restriction fragment length polymorphism (RFLP) method using blood samples. We have developed a novel method for determining the NAT2 and CYP2C19 genotypes using genomic DNA extracted from single hairs, buccal cells and fingernail. The $\mathrm{N}$-acetylation activity for procainamide and isoniazid was well correlated with NAT2 genotypes. Furthermore, we have first found that the anti- $\mathrm{H}$. pylori efficacy of omeprazole can be related to the CYP2C19 genotype, that is, the eradication effect of omeprazole with amoxicillin was highly efficient in CYP2C19 poor metabolizers, suggesting that CAM or metronidazole needs not to be used for this group on the first line therapy. Genotyping by PCR-RFLP, which is a simple in vitro test, can provide a new strategy to choose an optimal regimen based upon the individual genotype.

\section{[REFERENCES]}

1) Okumura K, Kita T, Chikazawa S, Komada F, Iwakawa S and Tanigawara Y: Genotyping of N-acetylation polymorphism and correlation with procainamide metabolism. Clin Pharmacol Ther 61: 509-517, 1997.

2) 喜多知子、廣野満喜、租本博雄、駒田富佐夫、谷川原祐介、奥村勝彦: 非血液検体を用いた CYP2C19 多型の遺伝子タイピング : 臨床薬理 28:277-278, 1997.

3) Tanigawara Y, Kita T, Aoyama N, Shirakawa K, Komada F, Kasuga M, Okumura K: Relationships between P450 genotype and efficacy of omeprazole for the treatment of $H$. pylori infection. American Gastroenterological Association and American Association for the Study of Liver Diseases., Washington D.C., May 1997. 